\title{
On the possible extinction of bird species in the Upper Paraná River floodplain, Brazil
}

\author{
Mendonça, LB. ${ }^{\text {** }}$, Lopes, EV. ${ }^{\mathrm{a}}$ and Anjos. L. ${ }^{\mathrm{b}}$

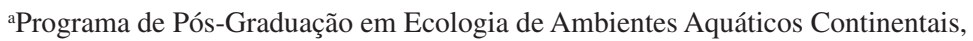 \\ Universidade Estadual de Maringá - UEM, \\ Av. Colombo, 5790, PEA, Bloco G90, CEP 87020-900, Maringá, PR, Brazil \\ ${ }^{\text {b}}$ Departamento de Biologia Animal e Vegetal, Universidade Estadual de Londrina - UEL, \\ CP 6001, CEP 86051-970, Londrina, PR, Brazil \\ *e-mail: lucianabaza@yahoo.com.br
}

Received November 25, 2008 - Accepted March 10, 2009 - Distributed June 30, 2009

\begin{abstract}
The Upper Paraná River floodplain (UPR) represents the last stretch of the Paraná River in Brazilian territory where a river-floodplain ecosystem still exists. However, the region had been subjected to intense deforestation in previous decades, and more than half of the original floodplain has been lost due to the construction of the Porto Primavera dam, which may have resulted in the local extinction of species. In the present study, we compared the list of bird species recorded before the construction of Porto Primavera dam (1926-1996) to that gotten afterwards (1999-2007) under the Long-Term Ecological Research program (LTER-site 6). We aim to investigate biogeographical and ecological traits of species potentially lost in the UPR. Endemism, proximity to the edge of species' geographic range, low tolerance to human-altered habitats and habitat specificity were associated to the potential extinction of birds in the UPR. The region represents an important opportunity for conservation, and should be target of conservation efforts to avoid further loss of species and ecological processes.
\end{abstract}

Keywords: local extinction, birds, Atlantic Forest, floodplain.

\section{Sobre a possível extinção de aves da planície alagável do Alto Rio Paraná, Brasil}

\begin{abstract}
Resumo
A planície alagável do Alto Rio Paraná (ARP) representa o último trecho do Rio Paraná em território brasileiro em que ainda existe um extensivo ecossistema do tipo rio-planície alagável. No entanto, a região sofreu intenso processo de desmatamento nas décadas passadas e mais da metade da extensão original da planície foi perdida com a formação do lago da usina hidrelétrica de Porto Primavera, o que pode ter resultado na extinção local de espécies. No presente estudo, comparou-se a lista de espécies de aves registradas no ARP antes da construção da referida usina (1926-1996) com aquelas registradas após este período (1999-2007) no âmbito do programa de Pesquisas Ecológicas de Longa Duração (PELD-sítio 6), com o objetivo de investigar características biogeográficas e ecológicas das espécies potencialmente extintas no local. Endemismo, proximidade das espécies de seus limites de distribuição geográfica, baixa tolerância a habitats alterados e especificidade de habitat podem estar associados à perda de espécies no ARP. A região representa uma importante oportunidade para a conservação e deve receber esforços para evitar a perda futura de espécies e de processos ecológicos.
\end{abstract}

Palavras-chave: extinção local, avifauna, Floresta Atlântica, planície alagável.

\section{Introduction}

The rate at which humans are changing natural landscapes, in general terms, is much higher than that seen through the dynamics of disturbance in natural ecosystems (Tabarelli and Gascon, 2005), and habitat loss and fragmentation are perhaps the main factors associated to loss in biodiversity (Marini and Garcia, 2005; Tabarelli and Gascon, 2005; IUCN, 2008). The floodplain located at the border of the States of Paraná and Mato Grosso do

Sul (Brazil), is within the last non-dammed section of the Paraná River in Brazil. This area, called in the present study as the Upper Paraná River floodplain (UPR), represents the last stretch of the Paraná River in Brazilian territory where a river-floodplain ecosystem still exists, and is one of the last well preserved areas of the Paraná River wetlands (Agostinho et al., 2004). However, the local extinction of species is potential, given that the region 
had been subjected to intense deforestation in previous decades due to human colonization (Agostinho, 1997; Campos and Souza, 1997). Moreover, the construction of the Porto Primavera hydroelectric plant has created a large water reservoir, which has possible implications on the dynamics of local plant and animal populations.

Originally, the UPR stretched over nearly $480 \mathrm{~km}$, especially over the right bank system of the river in the State of Mato Grosso do Sul. With the formation of the reservoir lake of the Porto Primavera hydroelectric plant (1998-2001), more than half of this ecosystem was lost. Even so, the remaining portion, extending roughly $230 \mathrm{~km}$, represents a biodiverse ecosystem, which is considered a priority for conservation (MMA, 2003; Agostinho et al., 2004). This region has been designated a conservation unit by the Federal Government: the "Área de Proteção Ambiental das Ilhas e Várzeas do Rio Paraná". The mouth of the Ivinhema River (an important tributary of the Paraná River), also included in the area, belongs to the "Parque Estadual das Várzeas do Rio Ivinhema", a state park. The UPR is also included in the Atlantic Forest Biosphere Reserve, of the Unesco-MAB program. Since 1999, this area has been studied under the Long Term Ecological Research program identified as site 6 (LTER-site 6; Agostinho et al., 2004). LTERsite 6 comprises a large group of researchers studying social, physical and biological aspects of UPR; the avifauna is one of the groups of organisms studied.

The avifauna of the UPR and adjacent areas is highly diverse due to the mosaic of habitats in the region; the aquatic, terrestrial and transitional environments form a complex mosaic. In addition, the UPR is located is a transition zone between the Atlantic Forest and the Cerrado (Ab'Sáber, 2003; Souza et al., 2004), and their respective endemic areas (Porzecanski and Cracraft, 2005). It is also influenced by the Chaco (Campos and Souza, 1997). The first ornithological records in the UPR date from 1920s (Sztolcman, 1926). Aftewards, Straube et al. (1996) organized an annotated checklist of the avifauna of the northwestern Paraná and bordering areas, including the UPR region. The paper of Straube et al. brings together previously information on species records, based on literature, museum specimens and their own field observations. In addition, short-term surveys of bird species were conduced as part of the environmental diagnostic for the construction of the Porto Primavera hydroelectric plant (Themag and Engea, 1994). After the construction of Porto Primavera dam (1998-2001), ornithological studies in the UPR have been carried out, under the LTER-site 6 program, since 1999 (Gimenes and Anjos, 2004; 2006; 2007; Loures-Ribeiro and Anjos, 2004; 2006; Mendonça et al., 2004; Mendonça and Anjos, 2006; ongoing studies). The list of birds recorded in those studies is presented in Gimenes et al. (2007), together with additional records made by Gimenes and collaborators; this list encompasses all records of bird species obtained under the LTER-site 6. Considering all inventories, 372 bird species are accounted for the UPR.
Comparisons between historical data and recent inventories are important when assessing extinction processes (Ribon et al. 2003). In the present study, we compared the list of bird species recorded in the period from 1926-1996 to that gotten from 1999-2007 (referred here as currently recorded species; CR species). We aim to investigate biogeographical and ecological traits of species potentially lost (referred here as PL species), when these two lists are compared.

\section{Material and Methods}

\subsection{Study area}

The section of the UPR and bordering areas considered in the present study, corresponds to the segment between the reservoir lake of the Porto Primavera hydroelectric plant and the upper mouth of the Ivinhema River ( $22^{\circ} 32^{\prime} \mathrm{S}$ to $22^{\circ} 59^{\prime} \mathrm{S}$ and $53^{\circ} 08^{\prime} \mathrm{W}$ to $53^{\circ} 4^{\prime} \mathrm{W}$; $230 \mathrm{~m}$ a. s. 1.). The region's climate is classified as Cfa (tropical-subtropical), with a mean annual temperature of $22{ }^{\circ} \mathrm{C}\left(26^{\circ} \mathrm{C}\right.$ in summer and $19{ }^{\circ} \mathrm{C}$ in winter $)$ and a mean annual rainfall of $1,500 \mathrm{~mm}$ (Centrais Elétricas do Sul do Brasil, 1986).

Currently, the original forest cover of the UPR (seasonal semi-deciduous forest) is reduced to small remnants located in areas close to the Paraná River and its islands (Campos and Souza, 1997), in a matrix dominated by agricultural and pasture lands. The landscape of UPR is a complex mosaic that includes forest remnants (rarely exceeding $300 \mathrm{ha}$ ), stretches of riparian vegetation, marsh forests, buriti palm groves, shrubby vegetation, grasslands, and wetlands. Besides the segments of large rivers - such as the Paraná, Ivinhema and Baía (the latter situated completely within the floodplain) - floodplain lakes, secondary channels, over 100 islands, sandy and swampy beaches are found in the region.

\subsection{Ornithological data}

The list of bird species found in the UPR and bordering areas prior to the formation of the Porto Primavera reservoir (1926-1996) was obtained in Themag and Engea (1994) and Straube et al. (1996). The list of birds recorded after this period (1999-2007) was obtained in Gimenes et al. (2007).

Two features of the biogeographical distribution of birds were considered: 1) endemism and 2) the position of the UPR in relation to the edge of species' geographic range. Species with geographic distribution restricted either to the Atlantic Forest (ATL) or the Central South American (CSA) zoogeographical regions according to Parker III et al. (1996) were considered endemics. The position of UPR in relation to the edge of species' range was defined considering the following classes of distance: up to $100 \mathrm{~km}, 100-200 \mathrm{~km}, 200-500 \mathrm{~km}$ and over $500 \mathrm{~km}$. Distances were estimated from species' range maps (Ridgely et al., 2007), by measuring the distance between the approximate central point of the area studied and the closest edge of species' range. This estimate 
was performed using the software ArcExplorer 9.2. For species whose distributions do not include the UPR (Ridgely et al., 2007), a zero value was adopted for the distance to their edge of geographic range, assuming that the recording of the species at the location represents a new limit for its range.

The ecological traits considered were: 1) habitat use, 2) tolerance to habitat alteration, 3) habitat specificity, and 4) diet. Habitat use: species were classified as forest species, which occur in the interior and/or edges of forests; semi-open species, observed more often in non-forest habitats such as shrubby vegetation and open areas; species that inhabit both forests and semi-open habitats; aquatic species, whose feeding or reproduction depends directly on aquatic habitats. Classification was based mostly on Parker III et al. (1996). Tolerance to habitat alteration: species that can occur in human-altered habitats, such as second-growth forest and woodlands, pastures and agricultural lands, and second-growth scrub (habitats F15, N13 and N14 sensu Parker III et al., 1996) were considered tolerant to human-altered habitats. Habitat restriction: species that occur in only one habitat type according to Parker III et al. (1996) were considered habitat restricted. Diet: species were classified as omnivores, insectivores, carnivores, frugivores, or nectarivores according to Del Hoyo et al. (1992-2005). For species not included in Del Hoyo et al. (1992-2005), we considered diets reported by Ridgely and Tudor (1989, 1994), Sick (1997), and Isler and Isler (1999).

A RxC test for independency (Chi-square test) was used to evaluate significance (alfa $=0.05$ ) between species number in different categories when the expected frequencies were equal ot geater than five (Fowler and Cohen, 1986). We compared the proportions of each category for the CR bird species with the PL ones.

\section{Results}

From the total of 372 bird species recorded to the UPR, $77(21 \%)$ were not recorded in the period from 1999-2007. Those 77 bird species were considered here as possibly locally extinct (Appendix).

The rates of endemic/non endemic species were significantly different for the $\mathrm{CR}$ and PL bird species groups (Chi-square $=14.2 ; \mathrm{DF}=1 ; \mathrm{P}<0.0001$ ); endemic species are more likely to become extinct, as they were better represented in the PL group (Table 1). Regarding the position of the UPR in relation to the edge of species' range, there was a significant difference in the proportions of species in classes of distance (up to $100 \mathrm{~km}, 100-200 \mathrm{~km}, 200-500 \mathrm{~km}$, and over $500 \mathrm{~km}$ ) comparing $\mathrm{CR}$ and PL species (Chi-square = 52.8; $\mathrm{DF}=3 ; \mathrm{P}<0.0001)$. Bird species close to the edge of their geographical range (up to $100 \mathrm{~km}$ ) seem to be more extinction prone. In contrast, those that are far from their range limit ( $>500 \mathrm{~km}$ ) seem more likely to persist in the UPR landscape (Table 1).
The distribution of species within habitat categories differed between PL and CR groups (Chi-square = 9.36; $\mathrm{DF}=3 ; \mathrm{P}=0.025)$. Species associated to semi-open habitats seem to be the ones more negatively affected by landscape alteration in the UPR; a higher proportion of species in this category was observed in the PL group (Table 1). The rates of species that are tolerant/ not tolerant to human-altered habitats were also different between the PL and RC groups (Chi-square = 43.7; $\mathrm{DF}=1 ; \mathrm{P}<0.0001)$. The $\mathrm{PL}$ group was composed mostly of not tolerant species while the CR group had a greater proportion of species that are tolerant to altered habitats (Table 1). Similarly, habitat specificity differed between PL and CR groups (Chi-square $=6.72 ; \mathrm{DF}=1$; $\mathrm{P}<0.01$ ), with a greater proportion of habitat restricted species being observed in the former group (Table 1). The only ecological trait that did not show a significant difference between the two groups of species was diet (Chi-square $=0.838 ; \mathrm{DF}=4 ; \mathrm{P}=0.93$ ). Similar proportions of frugivores, insectivores, carnivores, nectarivores and omnivores were observed in the PL and CR groups

Table 1. Proportion of species currently recorded (CR species) and potentially lost (PL species) in the Upper Paraná River floodplain in categories of biogeographical and ecological traits.

\begin{tabular}{|c|c|c|}
\hline Traits & $\begin{array}{c}\text { CR species } \\
\text { (295) }\end{array}$ & $\begin{array}{c}\text { PL species } \\
\text { (77) }\end{array}$ \\
\hline \multicolumn{3}{|l|}{ Endemism } \\
\hline Endemics & 8 & 23 \\
\hline \multicolumn{3}{|c|}{ Distance from edge of geographical range } \\
\hline Up to $100 \mathrm{~km}$ & 18 & 56 \\
\hline $100-200 \mathrm{~km}$ & 10 & 10 \\
\hline $200-500 \mathrm{~km}$ & 30 & 21 \\
\hline$>500 \mathrm{~km}$ & 42 & 13 \\
\hline \multicolumn{3}{|l|}{ Habitat use } \\
\hline Forest & 35 & 26 \\
\hline Forest and semi-open & 25 & 16 \\
\hline Semi-open & 20 & 34 \\
\hline Aquatic & 20 & 25 \\
\hline \multicolumn{3}{|c|}{ Tolerance to human-altered habitats } \\
\hline Tolerant species & 62 & 19 \\
\hline \multicolumn{3}{|l|}{ Habitat specificity } \\
\hline Habitat-restricted species & 8 & 18 \\
\hline Others & 92 & 82 \\
\hline \multicolumn{3}{|l|}{ Diet } \\
\hline Omnivores & 33 & 31 \\
\hline Insectivores & 34 & 38 \\
\hline Frugivores & 11 & 9 \\
\hline Carnivores & 20 & 18 \\
\hline Nectarivores & 3 & 4 \\
\hline
\end{tabular}


(Table 1). These tendencies (tolerance to human-altered habitats, habitat specificity, and diet) were also observed for each class of habitat use (forest, forest to semiopen, semi-open, and aquatic) individually (Chi-square; $\mathrm{p}<0.05$ for all tests).

Species that displayed at least two of the traits considered in the present investigation (endemism, proximity to the edge of species' range, low tolerance to human-altered habitats, and habitat specificity) were frequent in the PL group (60\%; Appendix). Four species, Tinamus solitarius (Vieillot, 1819), Philydor lichsteinsteini Cabanis and Heine, 1859, Charitospiza euscoma Oberholser, 1905, and Geositta poiciloptera (Wied, 1830) displayed all four traits. Only $8 \%$ of species in the PL group did not show any of these traits. With the exception of Tachyphonus coronatus (Vieillot, 1822), endemism was combined with other traits for all PL species: $61 \%$ of endemic birds analyzed were close to the edge of their ranges, $94 \%$ were considered not tolerant to human-altered habitats, $27 \%$ were habitatrestricted, and for $39 \%$, endemism was combined with the first two traits. All habitat-restricted species and $81 \%$ of those found close to the edge of their ranges appeared to be not tolerant of human-altered habitats (Appendix).

\section{Discussion}

The present study has demonstrated that endemism, proximity to the edge of species' geographic range, low tolerance to human-altered habitats and habitat specificity are all traits associated to the potential loss of species in the UPR. These features are frequently mentioned in the literature as being associated with increased extinction risk in birds (Stotz et al., 1996; Christiansen and Pitter, 1997; Goerk, 1997; Ribon et al., 2003; Gage et al., 2004; Kattan et al., 1994; Sodhi et al., 2004; Anjos, 2006; Lees and Peres, 2008). The fact that the study area is quite large makes it difficult to confirm extinction, particularly for some bird species that are difficult to detect. However, we believe that the species listed in the present study are probably locally extinct, or had their populations considerably reduced. Most species displayed at least two of the traits considered here; three of the four species that displayed all four traits (Tinamus solitarius, Charitospiza euscoma, and Geositta poiciloptera) are Near Threatened at the global level (IUCN, 2008).

Endemism can be used as a criterion for identifying species at risk. Moreover, areas with a high number of endemic species (e.g. Atlantic Forest) are often considered priorities for conservation (Stotz at al., 1996; Myers et al., 2000; Silva et al., 2004; Bencke et al., 2006). Considering the fact that the UPR is in a transition zone between the Atlantic Forest and Cerrado, it is not a surprise that several species have range limits that are close to this region. This feature was shown to be an important factor in the group of PL species analyzed. Species at the edges of their ranges are likely more vulnerable to habitat loss and fragmentation; populations may be at their physiological and ecological limits at their distributional edge; they often present low densities, and thus could be particularly vulnerable to genetic and/or environmental stresses (Gaston, 2003; Sodhi et al., 2004).

Of the ecological features, habitat specificity was a frequent trait among the species in the PL group. Habitat loss and fragmentation are strong forces driving to extinction, as have been argued by several authors (e.g. Debinski and Holt, 2000; Laurence, 2008), and species with narrow habitat requirements should be particularly sensitive to habitat loss and fragmentation (Kattan, 1994; Goerk, 1997; Henle et al., 2004). Low tolerance to human-altered habitats decreases the chances of species survival (Stotz et al., 1996), possibly due to variations in resources, such as food availability and nest sites.

With regard to the four categories of habitat considered in the present study, species associated to semiopen habitats seemed to be the most affected by landscape modification in the UPR. The semi-open habitat was severely affected by the artificial lake of the Porto Primavera hydroelectric plant, which covered an extensive area of non-forested habitats. This could explain the high rate of semi-open species in the PL group. In addition, of the semi-open habitat PL species, 27\% are endemic (all of them to the CSA zoogeographical region), $73 \%$ are close (up to $100 \mathrm{~km}$ ) to edge of their geographic ranges, and $81 \%$ appear not to be tolerant to human-altered habitats.

Although some species are likely to have been lost in the region, the UPR still supports a rich avifauna, including species of conservation concern at the regional or global levels, such as Harpyhaliaetus coronatus (Vieillot, 1817) (Mikich and Bérnils, 2004; IUCN 2008). Also, Crax fasciolata Spix, 1825, Anhima cornuta (Linnaeus, 1766), Ara ararauna (Linnaeus, 1758), and Ara chloropterus Gray, 1859, considered to be Endangered or Critically Endangered in the State of Paraná (Mikich and Bérnils, 2004) are currently found, in the mentioned State, mostly in the valley of the Paraná River.

Data presented here highlights the importance of UPR for the biodiversity of the region. It has been suggested that bird extinctions in the Atlantic Forest could be associated to the loss of floodplains and lowland forests (e.g. Ribon et al., 2003). Indeed, well-preserved extensive river-floodplain environments such as the UPR are becoming scarcer in the Atlantic Forest region, and thus should be target of conservation efforts to prevent further loss of species and ecological processes. Moreover, where major zoogeographic zones meet, as occurs in the UPR where the Atlantic Forest and Central South America zones come into contact, diverse ecological communities can be found, and preserving such areas is a major global priority (Stotz et al., 1996).

Acknowledgements - Financial support for this study was provided by CNPq (The National Council for Scientific and Technological Development, Brazil) through the LTER-site 6 program and research/doctorate grants. 


\section{References}

AB'SÁBER, AZ., 2003. Os domínios de natureza no Brasil: potencialidades paisagistíticas. São Paulo: Ateliê Editorial. $160 \mathrm{p}$

AGOSTINHO, AA., 1997. Qualidade dos habitats e perspectivas para a conservação. In VAZZOLER, AEAM., AGOSTINHO, AA. and HAHN, NS. (Eds.). A planície de inundação do alto rio Paraná: aspectos físicos, biológicos e socioeconômicos. Maringá: Eduem. p. 455-460.

AGOSTINHO, AA., RODRIGUES, L., GOMES, LC., THOMAZ, SM. and MIRANDA, LE., 2004. Structure and functioning of the Paraná river and its floodplain. Maringá: Eduem. 275p.

ANJOS, L., 2006. Bird species sensitivity in a fragmented landscape of the Atlantic forest in southern Brazil. Biotropica, vol. 38 , no. 2 , p. $229-234$.

BENCKE, GA., MAURICIO, GN., DEVELEY, PE. and GOERK, JM., 2006. Áreas importantes para a conservação das aves no Brasil: parte I - Estados do Domínio da Mata Atlântica. São Paulo: SAVE Brasil. 494p.

CAMPOS, JB. and SOUZA, MC., 1997. Vegetação. In VAZZOLER, AEAM., AGOSTINHO, AA. and HAHN, NS. (Eds.). A planície de inundação do alto rio Paraná: aspectos físicos, biológicos e socioeconômicos. Maringá: Eduem. p. 331-342.

Centrais Elétricas do Sul do Brasil - ELETROSUL, 1986. Ilha Grande: a vegetação da área de influência do reservatório da Usina Hidrelétrica de Ilha Grande (PR/MS). Florianópolis: ELETROSUL. Levantamento na escala 1:250.000. Relatório de pesquisa. 52p. Vol. 4.

CHRISTIANSEN, MB. and PITTER, E., 1997. Species loss in a forest bird community near Lagoa Santa in Southeastern Brazil. Biological Conservation, vol. 80, no. 1, p. 23-32.

Comitê Brasileiro de Registros Ornitológicos - CBRO, 2007. Lista das aves do Brasil. [S.L.]: CBRO. Available from: <http:// www.cbro.org.br/CBRO/listabr.htm>. Access in: 25 de Junho de 2008.

DEBINSKI, DM. and HOLT, RD., 2000. A survey and overview of habitat fragmentation experiments. Conservation Biology, vol. 14 , no. 2, p. 342-355

Del HOYO, J., ELLIOTT, A. and SARGATAL, J., 1992-2005. Handbook of the birds of the world. Barcelona: Lynx Editions. Vol. 1-10.

FOWLER, J. and COHEN, L., 1986. Statistics for ornithologists. Thetford: British Trust for Ornithology. 176p.

GAGE, GS., BROOKE, ML., SYMONDS, MRE. and WEGE, D., 2004. Ecological correlates of the threat of extinction in Neotropical bird species. Animal Conservation, vol. 7, no. 2, p. $161-168$.

GASTON, KJ., 2003. The structure and dynamics of geographic ranges. Oxford: Oxford University Press. 276p.

GIMENES, MR. and ANJOS, L., 2004. Spatial distribution of birds on three islands in the Upper River Paraná, southern Brazil. Ornitologia Neotropical, vol. 15, no. 1, p. 71-85.

2006. Influence of lagoons size and prey availability on the wading birds (Ciconiiformes) in the Upper Paraná
River floodplain, Brazil. Brazilian Archives of Biology and Technology, vol. 49, no. 3, p. 463-473.

2007. Variação sazonal na sociabilidade de forrageamento das garças Ardea alba (Linnaeus, 1758) e Egretta thula (Molina, 1782) (Aves: Ciconiiformes) na planície alagável do alto rio Paraná, Brasil. Revista Brasileira de Ornitologia, vol. 15 , no. 3 , p. 409-416.

GIMENES, MR., LOPES, EV., RIBEIRO, AL., MENDONÇA, LB. and ANJOS, L., 2007. Aves da planície alagável do alto rio Paraná. Maringá: Eduem. 281p.

GOERK, JM., 1997. Patterns of rarity in the birds of the Atlantic forest of Brazil. Conservation Biology, vol. 11, no. 1, p. $112-118$

HENLE, K., DAVIES, KF., KLEYER, M., MARGULES, C. and SETTELE, J., 2004. Predictors of species sensitivity to fragmentation. Biodiversity and Conservation, vol. 13, no. 1, p. $207-251$.

International Union for Conservation of Nature - IUCN, 2008. The IUCN red list of threatened species. [S.L.]: IUCN. Available from: <http://www.iucnredlist.org>. Access in: 20 de Fevereiro de 2009.

ISLER, ML. and ISLER, PR., 1999. The tanagers: natural history, distribution, and identification. Washington: Smithsonian Institution Press. 406p.

KATTAN, GH., ALVAREZ-LOPEZ, $\mathrm{H}$. and GIRALDO, M., 1994. Forest fragmentation and bird extinctions: San Antonio eighty years later. Conservation Biology, vol. 8, no. 1, p. $138-146$

LAURENCE, WF., 2008. Theory meets reality: how habitat fragmentation research has transcended island biogeographic theory. Biological Conservation, vol. 141, no. 7, p. 1731-1744.

LEES, AC. and PERES, CA., 2008. Avian life history determinants of local extinction risk in a fragmented neotropical forest landscape. Animal Conservation, vol. 11, no. 2, p. $128-137$

LOURES-RIBEIRO, A. and ANJOS, L., 2004. Ameaças aos senhores do ar. Ciência Hoje, vol. 35, no. 209, p. 66-69.

2006. Falconiformes assemblages in a fragmented landscape of the Atlantic Forest in southern Brazil. Brazilian Archives of Biology and Technology, vol. 49, no. 1, p. 149-162.

MARINI, MA. and GARCIA, FI., 2005. Bird Conservation in Brazil. Conservation Biology, vol. 19, no. 3, p. 665-671.

MENDONÇA, LB. and ANJOS, L., 2006. Flower morphology, nectar features, and hummingbird visitation to Palicourea crocea (Rubiaceae) in the Upper Paraná River floodplain, Brazil. Anais da Academia Brasileira de Ciências, vol. 78, no. 1, p. 45-57.

MENDONÇA, LB., GIMENES, MR. and ANJOS, L., 2004. Interactions between birds and other organisms in the Upper Paraná River floodplain, Brazil. In AGOSTINHO, AA., RODRIGUES, L., GOMES, LC., THOMAZ, SM. and MIRANDA, LE. (Eds.). Structure and functioning of the Paraná River and its floodplain. Maringá: Eduem. p. 215-220.

MIKICH, SB. and BÉRNILS, RS., 2004. Livro vermelho da fauna ameaçada no Estado do Paraná. Curitiba: Instituto Ambiental do Paraná. 1 CD-ROM.

Ministério do Meio Ambiente - MMA, 2003. Áreas prioritárias para a conservação, utilização sustentável e repartição de 
benefícios da biodiversidade brasileira. Brasília: Ministério do Meio Ambiente, Secretaria de Biodiversidade e Florestas, Projeto de Conservação e Utilização Sustentável da Diversidade Biológica Brasileira - PROBIO. 340p.

MYERS, NR., MITTERMEIER, A., MITTERMEIER, CG., FONSECA, GAB. and KENT, J., 2000. Biodiversity hotspots for conservation priorities. Nature, vol. 403 , no. 6772 , p. $853-858$

PARKER III, TA., STOTZ, DF. and FITZPATRICK, JW., 1996. Ecological and distribution databases. In STOTZ, DF., FITZPATRICK, JW., PARKER III, TA. and MOSKOVITS, DK. (Eds.). Neotropical birds: ecology and conservation. Chicago: University of Chicago Press. p. 131-436.

PORZECANSKI, AL. and CRACRAFT, J., 2005. Cladistic analysis of distributions and endemism (CADE): using raw distributions of birds to unravel the biogeography of the South American aridlands. Journal of Biogeography, vol. 32, no. 2, p. 261-275.

RIBON, R., SIMON, JE. and MATTOS, GT., 2003. Bird extinctions in Atlantic forest fragments of the Viçosa region, southeastern Brazil. Conservation Biology, vol. 17, no. 6, p. $1827-1839$.

RIDGELY, RS. and TUDOR, G., 1989. The birds of South America. Vol. 1. The oscine passerines. Austin: University of Texas Press. 562p.

1994. The birds of South America. Vol. 2. The suboscine passerines. Oxford: Oxford University Press. 940p.

RIDGELY, RS., ALLNUTT, TF., BROOKS, T., McNICOL, DK., MEHLMAN, DW., YOUNG, BE. and ZOOK, JR., 2007. Digital distribution maps of the birds of the Western Hemisphere, version 2.1. Arlington: NatureServe.

SICK, H., 1997. Ornitologia brasileira. Rio de Janeiro: Nova Fronteira. 904p.

SILVA, JMC., SOUSA, MC. and CASTELLETTI, CHM., 2004. Areas of endemism for passerine birds in the Atlantic forest,
South América. Global Ecology and Biogeography, vol. 13, no. 1, p. $85-92$.

SODHI, NS., LIOW, LH. and BAZZAZ, FA., 2004. Avian extinctions from tropical and subtropical forests. Annual Review of Ecology, Evolution and Systematics, vol. 35, p. 323-345.

SOUZA, MC., ROMAGNOLO, MB. and KITA, KK., 2004. Riparian vegetation: ecotones and plant communities. In THOMAZ, SM., AGOSTINHO, AA. and HAHN, NS. (Eds.). The upper Paraná river and its floodplain: physical aspects, ecology and conservation. Leiden: Backhuys Publishers. p. 353-367.

STOTZ, DF., FITZPATRICK, JW., PARKER III, TA. and MOSKOVITS, DK. (Eds.), 1996. Neotropical birds: ecology and conservation. Chicago: University of Chicago Press. 478p.

STRAUBE, FC. and URBEN-FILHO, A., 2001. Análise do conhecimento ornitológico da região noroeste do Paraná e áreas adjacentes. In ALBUQUERQUE, JLB., CÂNDIDO Jr., JF., STRAUBE, FC. and ROOS, AL. (Eds.). Ornitologia $e$ conservação: da ciência às estratégias. Tubarão: Unisul. p. 223-229.

STRAUBE, FC., BORNSCHEIN, MR. and SCHERER-NETO, P., 1996. Coletânea da avifauna da região Noroeste do Estado do Paraná e áreas limítrofes (Brasil). Arquivos de Biologia e Tecnologia, vol. 39, no. 1, p. 193-214.

SZTOLCMAN, J., 1926. Étude des collections ornithologiques de Paraná. Annales Zoologici Musei Polonici Historiae Naturalis, vol. 5, no. 3, p. 107-196.

TABARELLI, M. and GASCON, C., 2005. Lessons from fragmentation research: improving management and policy guidelines for biodiversity conservation. Conservation Biology, vol. 19 , no. 3, p. 734-739.

Themag Engenharia e Gerenciamento and ENGEA Avaliações, Estudo do Patrimonio e Engenharia - THEMAG/ENGEA, 1994. Usina Hidrelétrica Porto Primavera: estudo de impacto ambiental. São Paulo: CESP. Vol. 3. Diagnóstico do meio biótico. 
Appendix. Bioeographical and ecological traits of possibly extinct species in the Upper Paraná River floodplain (UPR): endemism, position of UPR in relation to the edge of species range (distance classes), habitat use, tolerance to habitat alteration (tolerance), habitat specificity, and diet. Species arranged according to their systematic and taxonomic position following the Brazilian Committee of Ornithological Records (CBRO 2008).

\begin{tabular}{|c|c|c|c|c|c|c|}
\hline Taxa & 馬 & 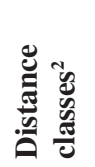 & 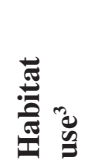 & 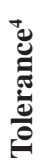 & 苞 & \\
\hline \multicolumn{7}{|l|}{ TINAMIDAE } \\
\hline Tinamus solitarius (Vieillot, 1819) & ATL & a & Fo & - & $\mathrm{x}$ & On \\
\hline Crypturellus obsoletus (Temminck, 1815) & - & a & Fo & - & - & On \\
\hline \multicolumn{7}{|l|}{ ANHIMIDAE } \\
\hline Chauna torquata (Oken, 1816) & - & $\mathrm{b}$ & $\mathrm{Aq}$ & - & $\mathrm{x}$ & On \\
\hline \multicolumn{7}{|l|}{ ANATIDAE } \\
\hline Sarkidiornis sylvicola Ihering and Ihering, 1907 & - & $\mathrm{d}$ & $\mathrm{Aq}$ & - & - & On \\
\hline Callonetta leucophrys (Vieillot, 1816) & - & $\mathrm{a}$ & $\mathrm{Aq}$ & - & - & On \\
\hline Netta erythrophthalma (Wied, 1832) & - & $\mathrm{a}$ & $\mathrm{Aq}$ & - & $\mathrm{x}$ & On \\
\hline Nomonyx dominica (Linnaeus, 1766) & - & $\mathrm{d}$ & $\mathrm{Aq}$ & - & $\mathrm{x}$ & On \\
\hline \multicolumn{7}{|l|}{ CRACIDAE } \\
\hline Aburria jacutinga (Spix, 1825) & ATL & $\mathrm{b}$ & Fo & - & - & $\mathrm{Fr}$ \\
\hline \multicolumn{7}{|l|}{ ODONTOPHORIDAE } \\
\hline Odontophorus capueira (Spix, 1825) & ATL & $\mathrm{b}$ & Fo & - & - & $\mathrm{Fr}$ \\
\hline \multicolumn{7}{|l|}{ PODICIPEDIDAE } \\
\hline Tachybaptus dominicus (Linnaeus, 1766) & - & $\mathrm{d}$ & $\mathrm{Aq}$ & - & - & In \\
\hline Podilymbus podiceps (Linnaeus, 1758) & - & $\mathrm{d}$ & $\mathrm{Aq}$ & - & - & $\mathrm{Ca}$ \\
\hline \multicolumn{7}{|l|}{ ARDEIDAE } \\
\hline Tigrisoma fasciatum (Such, 1825) & - & a & $\mathrm{Aq}$ & - & - & $\mathrm{Ca}$ \\
\hline Cochlearius cochlearius (Linnaeus, 1766) & - & $\mathrm{b}$ & $\mathrm{Aq}$ & - & - & $\mathrm{Ca}$ \\
\hline \multicolumn{7}{|l|}{ THRESKIORNITHIDAE } \\
\hline Plegadis chihi (Vieillot, 1817) & - & $\mathrm{c}$ & $\mathrm{Aq}$ & - & $\mathrm{x}$ & $\mathrm{Ca}$ \\
\hline \multicolumn{7}{|l|}{ ACCIPITRIDAE } \\
\hline Buteo swainsoni Bonaparte, 1838 & - & a & Fo-So & - & - & $\mathrm{Ca}$ \\
\hline Spizaetus tyrannus (Wied, 1820) & - & a & Fo-So & - & - & $\mathrm{Ca}$ \\
\hline \multicolumn{7}{|l|}{ FALCONIDAE } \\
\hline Ibycter americanus (Boddaert, 1783) & - & a & Fo & - & - & In \\
\hline Falco peregrinus Tunstall, 1771 & - & d & So & - & - & $\mathrm{Ca}$ \\
\hline \multicolumn{7}{|l|}{ RALLIDAE } \\
\hline Porzana flaviventer (Boddaert, 1783) & - & $\mathrm{b}$ & $\mathrm{Aq}$ & - & $\mathrm{x}$ & On \\
\hline Pardirallus maculatus (Boddaert, 1783) & - & a & $\mathrm{Aq}$ & - & $\mathrm{x}$ & In \\
\hline \multicolumn{7}{|l|}{ CHARADRIIDAE } \\
\hline Vanellus cayanus (Latham, 1790) & - & $\mathrm{c}$ & $\mathrm{Aq}$ & - & $\mathrm{x}$ & In \\
\hline Charadrius semipalmatus Bonaparte, 1825 & - & a & $\mathrm{Aq}$ & - & - & $\mathrm{Ca}$ \\
\hline \multicolumn{7}{|l|}{ SCOLOPACIDAE } \\
\hline Gallinago undulata (Boddaert, 1783) & - & $\mathrm{c}$ & $\mathrm{Aq}$ & - & - & $\mathrm{Ca}$ \\
\hline Tringa melanoleuca (Gmelin, 1789) & - & $\mathrm{d}$ & $\mathrm{Aq}$ & $\mathrm{x}$ & - & In \\
\hline Calidris melanotos (Vieillot, 1819) & - & $\mathrm{d}$ & $\mathrm{Aq}$ & - & - & $\mathrm{Ca}$ \\
\hline \multicolumn{7}{|l|}{ CUCULIDAE } \\
\hline Micrococcyx cinereus (Vieillot, 1817) & - & $\mathrm{c}$ & Fo-So & - & - & In \\
\hline \multicolumn{7}{|l|}{ STRIGIDAE } \\
\hline Megascops watsonii (Cassin, 1849) & - & a & Fo & - & - & $\mathrm{Ca}$ \\
\hline Asio stygius (Wagler, 1832) & & $\mathrm{c}$ & Fo-So & & & $\mathrm{Ca}$ \\
\hline
\end{tabular}


Appendix. Continued...

\begin{tabular}{|c|c|c|c|c|c|c|}
\hline Taxa & 氖 & 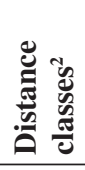 & 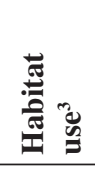 & 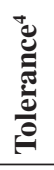 & 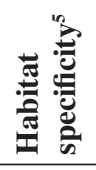 & \\
\hline \multicolumn{7}{|l|}{ CAPRIMULGIDAE } \\
\hline Chordeiles pusillus Gould, 1861 & - & a & So & - & - & In \\
\hline \multicolumn{7}{|l|}{ TROCHILIDAE } \\
\hline Chrysolampis mosquitus (Linnaeus, 1758) & - & $\mathrm{c}$ & So & - & - & $\mathrm{Ne}$ \\
\hline Amazilia versicolor (Vieillot, 1818) & - & $\mathrm{c}$ & Fo-So & $\mathrm{x}$ & - & $\mathrm{Ne}$ \\
\hline Calliphlox amethystina (Boddaert, 1783) & - & $\mathrm{c}$ & Fo-So & - & - & $\mathrm{Ne}$ \\
\hline \multicolumn{7}{|l|}{ ALCEDINIDAE } \\
\hline Chloroceryle aenea (Pallas, 1764) & - & a & $\mathrm{Aq}$ & - & - & $\mathrm{Ca}$ \\
\hline Chloroceryle inda (Linnaeus, 1766) & - & a & $\mathrm{Aq}$ & - & - & $\mathrm{Ca}$ \\
\hline \multicolumn{7}{|l|}{ BUCCONIDAE } \\
\hline Nystalus maculatus (Gmelin, 1788) & - & a & So & - & - & In \\
\hline \multicolumn{7}{|l|}{ RAMPHASTIDAE } \\
\hline Ramphastos dicolorus Linnaeus, 1766 & ATL & $\mathrm{b}$ & Fo & - & - & $\mathrm{Fr}$ \\
\hline Selenidera maculirostris (Lichtenstein, 1823) & ATL & a & Fo & - & - & $\mathrm{Fr}$ \\
\hline Pteroglossus bailloni (Vieillot, 1819) & ATL & a & Fo & - & - & $\mathrm{Fr}$ \\
\hline \multicolumn{7}{|l|}{ PICIDAE } \\
\hline Veniliornis mixtus (Boddaert, 1783) & CSA & a & So & - & - & In \\
\hline \multicolumn{7}{|l|}{ MELANOPAREIIDAE } \\
\hline Melanopareia torquata (Wied, 1831) & CSA & a & So & - & - & In \\
\hline \multicolumn{7}{|l|}{ THAMNOPHILIDAE } \\
\hline Thamnophilus torquatus Swainson, 1825 & CSA & a & So & - & - & In \\
\hline Thamnophilus punctatus (Shaw, 1809) & & a & Fo-So & $\mathrm{x}$ & - & In \\
\hline Herpsilochmus atricapillus Pelzeln, 1868 & CSA & $\mathrm{b}$ & Fo & - & - & In \\
\hline \multicolumn{7}{|l|}{ SCLERURIDAE } \\
\hline Geositta poeciloptera (Wied, 1830) & CSA & a & So & - & $\mathrm{x}$ & In \\
\hline \multicolumn{7}{|l|}{ FURNARIIDAE } \\
\hline Synallaxis albescens Temminck, 1823 & - & $\mathrm{c}$ & So & $\mathrm{x}$ & - & In \\
\hline Synallaxis hypospodia Sclater, 1874 & - & a & So & $\mathrm{x}$ & - & In \\
\hline Phacellodomus rufifrons (Wied, 1821) & - & a & Fo-So & $\mathrm{x}$ & - & In \\
\hline Philydor lichtensteini Cabanis and Heine, 1859 & ATL & $\mathrm{c}$ & Fo & - & $\mathrm{x}$ & In \\
\hline Philydor rufum (Vieillot, 1818) & - & $\mathrm{c}$ & Fo & - & - & In \\
\hline \multicolumn{7}{|l|}{ TYRANNIDAE } \\
\hline Elaenia cristata Pelzeln, 1868 & - & a & So & - & - & On \\
\hline Suiriri suiriri (Vieillot, 1818) & - & a & So & - & - & In \\
\hline Sublegatus modestus (Wied, 1831) & - & a & So & - & - & In \\
\hline Platyrinchus mystaceus Vieillot, 1818 & - & $\mathrm{c}$ & Fo & - & - & On \\
\hline Onychorhynchus coronatus (Statius Muller, 1776) & - & a & Fo & - & $\mathrm{x}$ & In \\
\hline Contopus cinereus (Spix, 1825) & - & $\mathrm{c}$ & Fo-So & $\mathrm{x}$ & - & In \\
\hline Xolmis cinereus (Vieillot, 1816) & - & d & So & $\mathrm{x}$ & - & In \\
\hline Philohydor lictor (Lichtenstein, 1823) & - & a & So & - & - & In \\
\hline Tyrannus albogularis Burmeister, 1856 & - & a & So & - & - & In \\
\hline \multicolumn{7}{|l|}{ PIPRIDAE } \\
\hline Neopelma pallescens (Lafresnaye, 1853) & - & a & Fo & - & - & On \\
\hline Manacus manacus (Linnaeus, 1766) & - & a & Fo & $\mathrm{x}$ & - & $\mathrm{Fr}$ \\
\hline Chiroxiphia caudata (Shaw and Nodder, 1793) & ATL & $\mathrm{b}$ & Fo & - & - & Fr \\
\hline
\end{tabular}


Appendix. Continued...

\begin{tabular}{|c|c|c|c|c|c|c|}
\hline Taxa & 氞 & 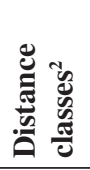 & 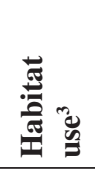 & 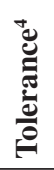 & 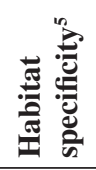 & 晜 \\
\hline \multicolumn{7}{|l|}{ TITYRIDAE } \\
\hline Pachyramphus castaneus (Jardine and Selby, 1827) & - & $\mathrm{c}$ & Fo & $\mathrm{x}$ & - & In \\
\hline \multicolumn{7}{|l|}{ HIRUNDINIDAE } \\
\hline Alopochelidon fucata (Temminck, 1822) & - & d & So & - & - & In \\
\hline \multicolumn{7}{|l|}{ POLIOPTILIDAE } \\
\hline Polioptila dumicola (Vieillot, 1817) & - & a & So & - & - & In \\
\hline \multicolumn{7}{|l|}{ THRAUPIDAE } \\
\hline Neothraupis fasciata (Lichtenstein, 1823) & CSA & a & Fo-So & - & $\mathrm{x}$ & On \\
\hline Cypsnagra hirundinacea (Lesson, 1831) & CSA & a & So & - & - & On \\
\hline Tachyphonus coronatus (Vieillot, 1822) & ATL & $\mathrm{c}$ & Fo-So & $\mathrm{x}$ & - & On \\
\hline Tachyphonus rufus (Boddaert, 1783) & - & $\mathrm{a}$ & So & $\mathrm{x}$ & - & On \\
\hline \multicolumn{7}{|l|}{ EMBERIZIDAE } \\
\hline Embernagra platensis (Gmelin, 1789) & - & a & So & - & - & On \\
\hline Sporophila plumbea (Wied, 1830) & - & c & So & - & - & On \\
\hline Sporophila maximiliani (Cabanis, 1851) & - & a & So & $\mathrm{x}$ & - & On \\
\hline Arremon taciturnus (Hermann, 1783) & - & $\mathrm{a}$ & Fo & - & $\mathrm{x}$ & On \\
\hline Charitospiza eucosma Oberholser, 1905 & $\mathrm{CSA}$ & a & So & - & $\mathrm{x}$ & On \\
\hline \multicolumn{7}{|l|}{ CARDINALIDAE } \\
\hline Saltator atricollis Vieillot, 1817 & CSA & a & So & - & - & On \\
\hline Cyanoloxia brissonii (Lichtenstein, 1823) & - & $\mathrm{d}$ & So & - & - & On \\
\hline \multicolumn{7}{|l|}{ ICTERIDAE } \\
\hline Procacicus solitarius (Vieillot, 1816) & - & a & Fo & $\mathrm{x}$ & - & On \\
\hline Cacicus cela (Linnaeus, 1758) & - & $\mathrm{a}$ & Fo-So & $\mathrm{x}$ & - & On \\
\hline
\end{tabular}

Abbreviations: ${ }^{1}$ ATL, species endemic to the Atlantic Forest; CSA, endemic to the Central South America; ${ }^{2}$ Abbreviations: a, up to $100 \mathrm{~km}$; b, 100-200 km; c, 200-500 km; d, more than $500 \mathrm{~km}$; ${ }^{3}$ Abbreviations: Fo, forest; Fo-So, forest to semiopen; So, semi-open; Aq, aquatic; ${ }^{4} \mathrm{An} \mathrm{x}$ indicates a species that can occur in human altered habitats (habitats F15, N13 and N14 sensu Parker III et al., 1996); ${ }^{5}$ An x indicates a habitat-restricted species (i.e. that occur in only one habitat type according to Parker III et al., 1996); and ${ }^{6}$ Abbreviations: On, omnivores; In, insectivores; Ca, carnivores; Ne, nectarivores. 